\title{
La recepción de “El Acorazado Potemkin" de Eisenstein en Zbigniew Rybczyński y Banksy
}

\author{
Ulrich BLANCHÉ \\ Univesidad de Heidelberg
}

Recibido: 15-11-2012 / Aceptado: 27-6-2013

RESUMEN: En el presente trabajo estudio la recepción de la famosa escena de la escalera de Odesa de la película muda "El acorazado Potemkin" (1925) de Sergej Eisenstein. Después de un breve repaso al contexto histórico de la película me centro en el video "Steps" (1987) del videoartista experimental y ganador de un Oscar, Zbigniew Rybczynski, el cual se basa en escena de Eisenstein. En la segunda parte del artículo estudio la recepción por parte del artista urbano Banksy de la imagen del carrito de bebé rodando abajo por las escaleras de Odessa.

Palabras clave: Arte urbano, Graffiti, Banksy, Eisenstein, Rybczyński, El Acorazado Potemkin, Los Intocables de Eliot Ness

ABSTRACT: In the present study I will deal with the reception of the famous Odessa Steps Scene from the silent movie "Battleship Potemkin" (1925) by Sergej Eisenstein. After a short historical over-view I discuss the video "Steps" (1987) by Oscar winning experimental video artist Zbigniew Rybczyński's, which is based on Eisenstein's scene. The second part of this essay deals with the street artist Banksy's reception of Eisenstein's pram rolling down the steps of Odessa. Key words: Street Art graffiti, Banksy, Eisenstein, Rybczyński, Battleship Potemkin, De Palma, The Untouchables

The movie posters for Eisenstein's "Battleship Potemkin" changed over time, earliest posters showed the dominant gun barrels of the battleship as the main subject together with the heroic rebels. Subsequent posters of this film that is listed on many "best movies of all time" lists, were based on the Odessa Steps scene, which is its' most famous scene. A more recent poster (fig. 1) united three motifs, for which the film is known today. The staircase scene as a whole, the scene with the baby pram rolling down the stairs and the woman with the pince-nez, who had been shot through her eye. In the present study I will deal with these motifs and their reception in art. I will exclude the painter Francis Bacon and his reception of the woman with the pince-nez, as there has already been written a lot about it. My focus will be on the video artist Zbigniew Rybczyński and the street artist Banksy.

\section{HISTORICAL BACKGROUND}

All the facts and arguments concerning the historical background are taken from 
Robert Rosentreter's book "Panzerkreuzer Potjomkin. Das Schiff. Der Aufstand. Der Film."1

Today some sources treat the - fictional -staircase scene in "Battleship Potemkin" at the end of the film as a historical fact. This scene occupies the fourth act of the revolutionary film, which Eisenstein called a tragedy in five acts. Although the film is based on historical facts, Eisenstein changed the story in order to achieve a dramatic climax. The reality of fiction was for Eisenstein closer to the actual reality.

On which historical facts does he base the movie on? The Russian Revolution took place between 1905 and 1907. Workers were starving in Saint Petersburg. 150,000 protested for more rights on the day that today is known as the "Bloody Sunday". About 200 of them were killed by tsarist troops. The protests and strikes spread nationwide. A mutiny took place on a vessel called "Potemkin" in 1905. After the vessels arrival in the Ukrainian port city Odessa, where a general strike had been going on, tsarist troops perpetrated a bloodbath while trying to suppress the unrest - but - in reality, not on the staircase shown in the movie. The riots were only partly successful. Reforms promised by the Tsarist Empire were soon withdrawn.

After the successful October Revolution of 1917, the "Potemkin" mutiny was glorified and implemented in Lenin's ideology. The reference to a failed revolution in a propaganda film is conclusive when considering the Leninist theory of revolution. The rebellious mass had lacked the necessary skills for a successful revolution and they did not have party cadres, as the Bolsheviks would later prove.

The "Knyaz Potemkin Tavrichesky" (Russian for "Prince Potemkin of Tauris") was a battleship of the Russian Navy, which belonged to the Black Sea Fleet. Because of

\footnotetext{
${ }^{1}$ Published in Rostock 2011. For further information see also http://www.steelnavy.com/CombrigPanteleimon.htm (4.2.13)
}

Eisenstein's film it has become known as "Battleship Potemkin". This term is based on a mistranslation. To wipe out the association with the mutiny, the ship was renamed in "Panteleimon" in 1906. It sunk in Sevastopol in 1919 and was scrapped in 1922. So Eisenstein shot the film not on the original ship but on the unrigged barbette ship "Dwenadzat Apostolov" (in English "Twelve Apostles"). This ship was used as a depot ship for mines in 1925. The cruiser "Komintern" was used as well. An interesting fact is, that the "Dwenadzat Apostolov" was involved in the persecution of the mutinous battleship "Knyaz Potemkin Tavrichesky" in 1905.

The staircase which today is called "The Potemkin Stairs", has 192 steps. It is located Odessa. This 142 meters long staircase leading from the inner city to the port was built in perspective: it is much wider at the bottom (21.7 meters) than at the top (13.4 feet), it looks as if it has the same width on the entire length - when seen from above. When seen from the bottom of the stairs, it seems to be considerably longer than it actually is.

The film was produced in the context of Soviet mass utopias. Eisenstein arranged a massive amount of people in it. This crowd is deconstructed by force on said theatrically illusionistic-built stairs. By that Eisenstein tries to produce pity and direct emotional affect in the observer.

\section{RYBCZYŃSKIS VIDEO “STEPS” (1987)}

In 2012 the ZKM (Center for Art and Media) in Karlsruhe honored the Oscar winning Polish experimental filmmaker Zbigniew Rybczyński (born 1949) in an exhibition called "The State of Image. Media Pioneers Zbigniew Rybczyński and Gábor Bódy". In this exhibition, the ZKM also showed the video "Steps". By using the blue screen technology, Rybczyński incorporated a voyeuristic group of then-contemporary stereotypical American tourists directly into Eisenstein's 
staircase scene (fig. 2). "I needed material that was immediately recognizable, and Eisenstein's was perfect. The Odessa Steps sequence is a rare scene, short, symbolic. It is a geometric situation, people are running, and soldiers are shooting. There is drama, a beginning and an end. Steps is an example of how technology changes, it is a film about technology. I had seven film cameras, four video cameras, and an infinite numbers of cables and wires."2, said Rybczyński.

The group, consisting of cynical young filmmakers, cynical punks, an US elite soldier who want to sell military secrets to the Soviets, stereotypical mothers, aggressive children, constantly photographing tourists and a black rapper who worships his boom box or ghetto blaster. They are led by an inept Slavic film director.

Rybczyński contrasts the hedonistic 1980s with the often as idealistic described 1920s. He shows his tourists, perhaps the Eisenstein crowd of today, in a very exaggerated way. They seem to be caricatures of themselves. Eisenstein's crowd meets a radical individualism, the yuppies of the 1980s and 90s. Lenin meets Gordon Gecko, the Greed-is-good-banker from the movie "Wall Street," which is also from 1987. Here the Russian workers uprising meets Brad Easton Ellis' American Psycho, predatory capitalism and Golf generation at the beginning of very idealistic communism. It is, as I said before, the year 1987. The Cold War had been going on for more than 40 years, armament and fear of communism ruled.

Rybczyński is also a director of Eastern European origin. Yet he portrays the tourists in clichés as Eisenstein does with his peasants, beggars and soldiers. They take pictures to prove that they have been there. If time traveling existed, according to Rybczyński, American tourists would even

\footnotetext{
${ }^{2}$ Zbigniew Rybczynski quoted in a video by Paola Hilda Melcher, Sara Petri und Gianluca Paoletti: Zbigniew Rybczynski: Notes For an Electronic Cinema, 1999. http://www.zbigvision.com/StepsFilm.html (4.2.13)
}

shoot photos during battle. Through photos and guns, Eisenstein's crowd is shot twice. First by soldiers, a second time by the tourist.

Rybczyński's serious, socio-critical approach is balanced by irony and a virtuoso demonstration of a at that time still new technology, the blue screen process. Eisenstein's staircase scene became working material for this postmodern "Wizard of OZ" from 1939. In this movie also color scenes of a red flag were juxtaposed in stark contrast with black and white scenes, to demonstrate a new technology, the color film. In 1982, a few years after Rybczyński was the first Polish film director to win an Oscar, he went to New York to produce music videos. Stunning new techniques played an important role in "Steps", "Tango" which won an academy award as well as in his music videos.

\section{BANKSY'S PRAM STENCIL IN CHICAGO}

Like Rybczyński, the Street Artist Banksy, well versed in almost all media, became a filmmaker. His mockumentary "Exit through the Gift Shop" from 2010 was nominated for an Oscar. In his illegal works on the streets Banksy refers to familiar images from the media. Some of them are taken from popular movies such as "Planet of Apes" or "Pulp Fiction". Why did the British artist choose the subject of a pram that seems to roll down a staircase for a stencil artwork in Chicago in 2010 (fig. 3)? The thought suggests itself he was influenced by Eisenstein's "Potemkin". The Odessa Steps Scene peaks with a pram carrying a baby rolling down the whole staircase. Eisenstein gave the stroller different functions. Mother and child represent parts of the mass; they are the faces of the crowd, which the viewer remembers. They make the vulnerability and suffering of the fleeing population of Odessa clear to the audience. The dramatic and strikingly slow death of the young mother accidently pushing her baby's pram down the stairs while dying has a dramatic 
fall denouement. A sailor dying in a fight would affect the viewer on a completely different level; it would have appeared to be more equal. But the mother is young, helpless, beautiful, and her child obviously still needs her. Her death is visualized by her dropping, which rushes her child accidentally to perdition. The rolling-down of the pram metaphorically stands for the wrong, the consequences of military violence and cruelty. The second purpose of the pram is to increase the tension as it goes down the stairs, the viewer is anxious as to the fate of the baby. Many things happen in Eisenstein's movie during the rolling down of the pram, this dramatic pointed single action functions as a frame, it connects the faster and faster cut sequences before the climax of the scene.

But what does Banksy do with Eisenstein's pram on a staircase? He found the cast, the shadow, the outline of a former staircase on a former inside wall of a warehouse which became an outside wall at the site of a recently demolished house. On this staircase he stenciled an old fashioned four wheel pram with folding top that recalls models from the 1960ies and earlier. Banksy often uses rather old fashioned props in his artworks as they have already become a stereotype which makes them more recognizable by more viewers. If the viewer looks at the photo in close-up (fig. 4) it becomes obvious that there is a baby in Banksy's pram. Two feet and a little hand, that is about to lose its' baby rattle. A vibrating bell is also clearly visible. They show Banksy at the high of his skills. The feet and the rattle in the air underline the dynamic motion, the shaking movement of the pram going down. The viewer can almost hear the rattling of the helter-skelter of the pram and the rattle.

According to self-expression, the Street Artist from Bristol collects ideas first and then walks around in cities to find a proper place for a specific artwork. Sometimes this process is reversed when Banksy gets inspired by interesting local conditions he found on walks to create new artworks for them.
In April 2009 Google Street View photographed the location ${ }^{3}$ Banksy used as canvas for this stencil work. Within a year an old warehouse building where the wall that Banksy used for spraying, obviously was pulled down. Latest at the beginning of May 2010 Banksy painted his pram there. Photos appeared soon after on his website and elsewhere on the internet. So is it most likely that Banksy just went there and found a wall that fit his purpose? Banksy was on a "cinematic mission": He had been on a graffiti spraying journey through the USA 2010, that preceded the premiere locations of his film and provided the necessary publicity for instance in New York, San Francisco or Los Angeles. So he created illegal artworks that were often connected with movies, a rat wearing old fashioned 3D glasses for instance or a camera operator who rips of a beautiful flower to see it close up. Most of them he customized in the narrower or wider sense to the location of these artworks. This customizing is a key element of Banksy's Street Art, the "street" part in his Street Art. All this also applies to Banksy's pram.

The London based artist found a particular wall to apply a creative idea for a stencil, which would not fit any wall, that is connected to film as he wanted to promote his movie. Furthermore the British tourist in the USA, Banksy, probably wanted Chicagos Version of the "Eiffel tower", the famous Willis (former Sears) Tower in the back of his artwork (fig. 3). Banksy even went a step further. The shape of the sprayed stroller and the proximity of to the Chicago Union Station speak for the first hypothesis, that Banksy went to Chicago with a finished concept in mind. Why did he choose this specific style of a pram? Is there a reason why the one in Eisenstein's movie looks completely different to the one Banksy used? And what has the Chicago Union Station, just ten blocks away from where Banksy placed

\footnotetext{
${ }^{3}$ I took a screen shot in June 2012, which stated the photo was taken in April 2009. In February 2013 it was replaced with a photo from June 2011 where Banksy's pram is clearly visible. http://goo.gl/maps/z66og (22.2.13)
} 
the pram have to do with Eisenstein's staircase scene? Both the style and the chosen location indicate one of the longest and most famous cinematic tributes to Eisenstein's Odessa Steps Scene. Strollers or similar vehicles dramatically rolling down stairs can be found in a satirically way in the famous Terry Gilliam movie "Brazil", in "The Simpsons" or the "Naked Gun". But it is used in a serious way, in a similar prominent position and length as in "Battleship Potemkin", in Brian de Palma's "Untouchables" from 1987. Here the show-down, this time not between soldiers and workers, but between police and mafia during prohibition happens on a staircase and finds its climax with a baby in a pram rolling down a prominent staircase, this time of the original staircase of the Chicago Union Station (fig. 5) which opened in 1925, the same year Eisenstein's movie was shot.

A stroller with a fabric folding top, folding top and almost equally large wheels can be found in De Palma's movie and as well in Banksy's stencil, but not in Eisenstein's "Battleship". But a "Battleship Potemkin" movie poster from $2011^{4}$ (fig. 6) depicts also such a pram in profile view with folding top similar to the one Banksy and De Palma used, although this poster is inconsistent with the film it advertised for. Also the slapstick-like character of the poster with the moronic grinning stuffed animal lion contrasts with the tragic content of the Eisenstein movie. The scene already had become cult; Eisenstein's dramatical seriousness was seen already more ironically by Gilliam and later by his landsman ${ }^{5}$ Banksy, but not or not very obviously by De Palma. Why is in figure 6 a silly grinning lion in the "Potemkin" stroller? The lion is a play on three successive settings of Eisenstein, of "speaking architecture" where

\footnotetext{
${ }^{4}$ On 30 May 2011 the website freakingnews.com started a pictogram movie poster contest, an artist who called himself Nonno on this site created this poster. http://www.freakingnews.com/Battleship-PotemkinMovie-Poster-Pictogram-Pics-96592.asp (22.2.13)

${ }^{5}$ Gilliam was born in USA but is typical for British humor since his Monty Python days.
}

three lion statues are seen, which rise, as the mass of people does. The first lion is shown asleep, the second erected, and the third is standing. Maybe the artist, who calls himself Nonno was aware of Banksy's artwork, as this stroller there has a lot in common with Banksy's. The grinning stuffed lion is the slapstick like equivalent of the baby with the rattle, Banksy's new creation.

It is still more likely Banksy made a local reference to "The Untouchables" than to Eisenstein. In his oeuvre Banksy always tries not to be seen as an art connoisseur but someone who refers to pictures the "man on the street" would recognize. He might have "The Untouchables" as a teenager. So Banksy's reference to the wall he uses, his canvas, is in this case not just about the actual, particular wall, but the city this wall is part of, Chicago and its history in real life and in movies. Banksy's stroller is a tribute to film, the city of Chicago and the concrete wall, which gave him the opportunity to demonstrate his virtuosity in the use of stencils in a special context, an illusionary wall in this case. For some, Banksy's stroller rolling down is just a funnydramatic slapstick-like scene that is reminiscent of comics, but for others it is a multilayered allusion to the history of film. Banksy's stencils often represent the fertile moment of a dramatic scene in an urban context. He pushed the pram down the stairs? Why? What happens to the baby? This artwork would not work so well elsewhere than in Chicago or Odessa, without the location reference, it would lose the "street" part in Street Art.

Nearly 80 years after its creation Eisenstein's "Potemkin" remains a strong inspiration for artists such as the Pet Shop Boys, who provided a musical version of the film, the band Arcade Fire, who made the music video for their political song "Intervention" completely from material of "Battleship Potemkin" in 2010 or the political graphics on the occasion of the re-election of Putin in 2012, who staged him in the role of the cruel captain of the "Potemkin". 


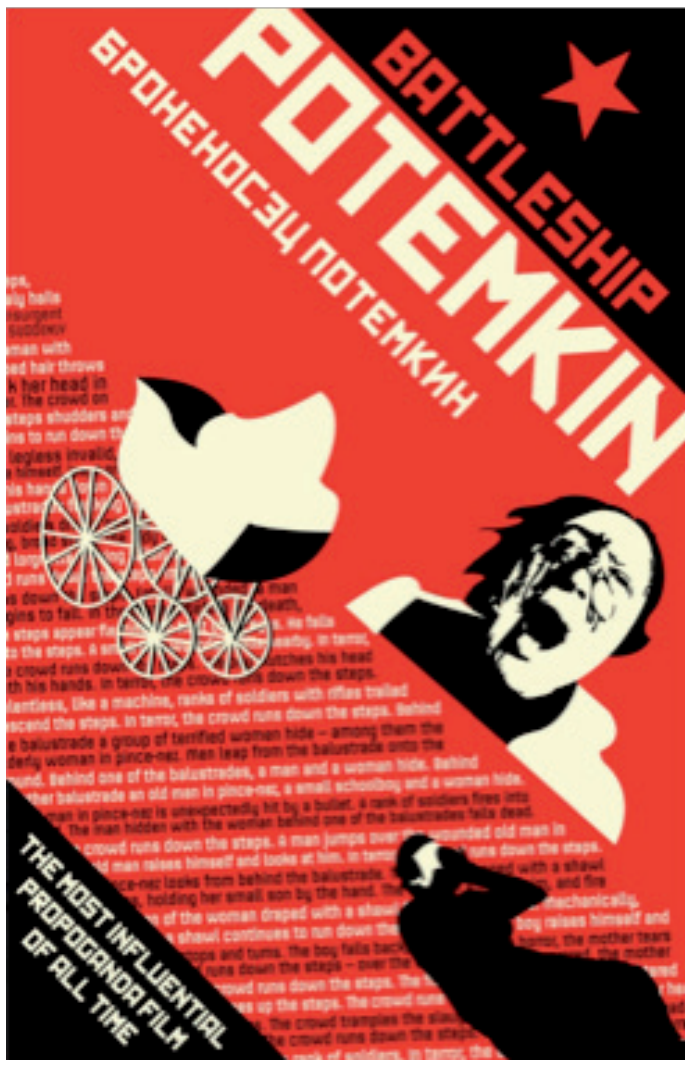

- Fig.1. Andrew James Stratton: Battleship Potemkin Type Poster (2011) - Part of an ongoing series of typographic posters dedicated to international silent films from the early 20th century. http://s3images.coroflot.com/user_files/individual_files/original_365239_VLYE_ASVLqa815hcDFmjywBHC.jpg (22.2.13)

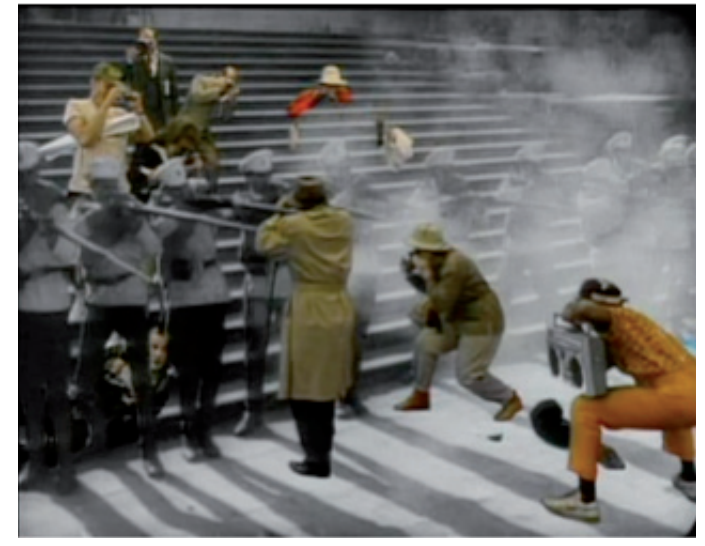

- Fig.2. Screenshot from Zbigniew Rybczyński: Steps (USA, 1987) http://www. videoex.ch/videoex2012/admin/downloads/142_steps_rybczynski_videoex.jpg (22.2.13) 

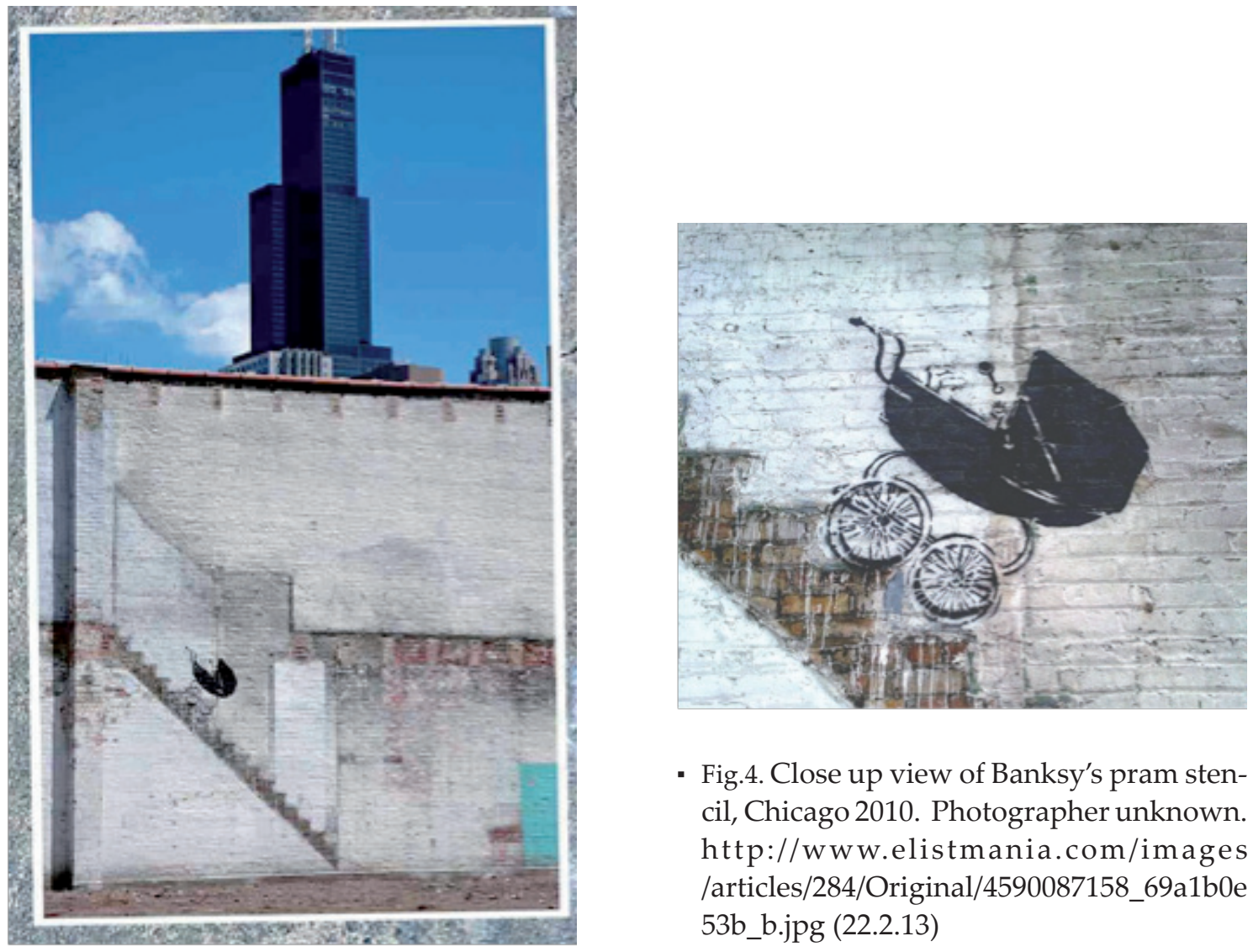

- Fig.4. Close up view of Banksy's pram stencil, Chicago 2010. Photographer unknown. http://www.elistmania.com/images /articles/284/Original/4590087158_69a1b0e 53b_b.jpg (22.2.13)

- Fig.3. Banksy's pram stencil, Chicago 2010. Photo originally from Banksy's website banksy.co.uk (May 2010). Can still be found on http://i51.photobucket.com/ albums/f369/djsilk/Banksy-Chicago.jpg (22.2.13) 


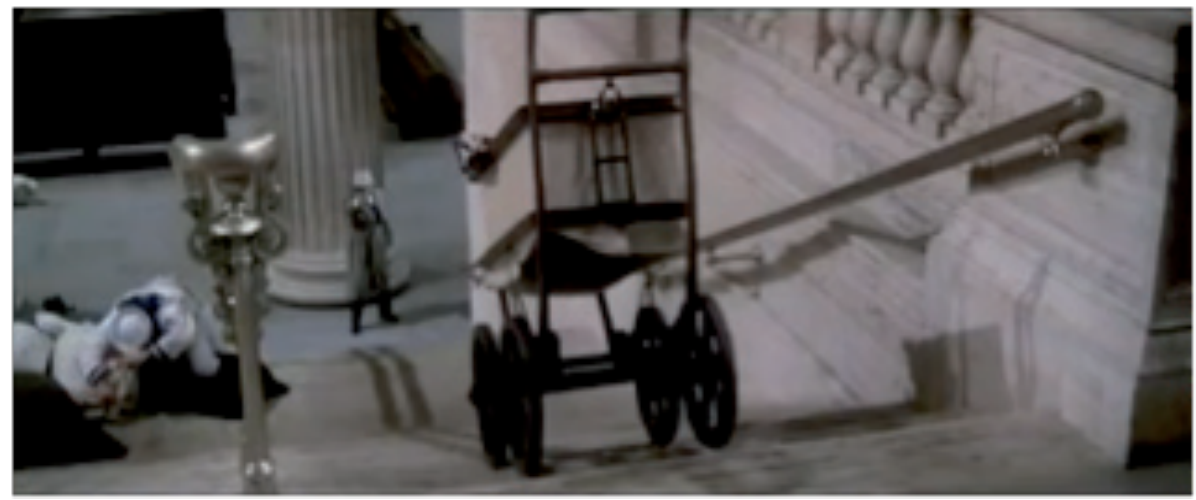

- Fig.5. Brian de Palma: The Untouchables (USA, 1987). Screenshot by Ulrich Blanché.

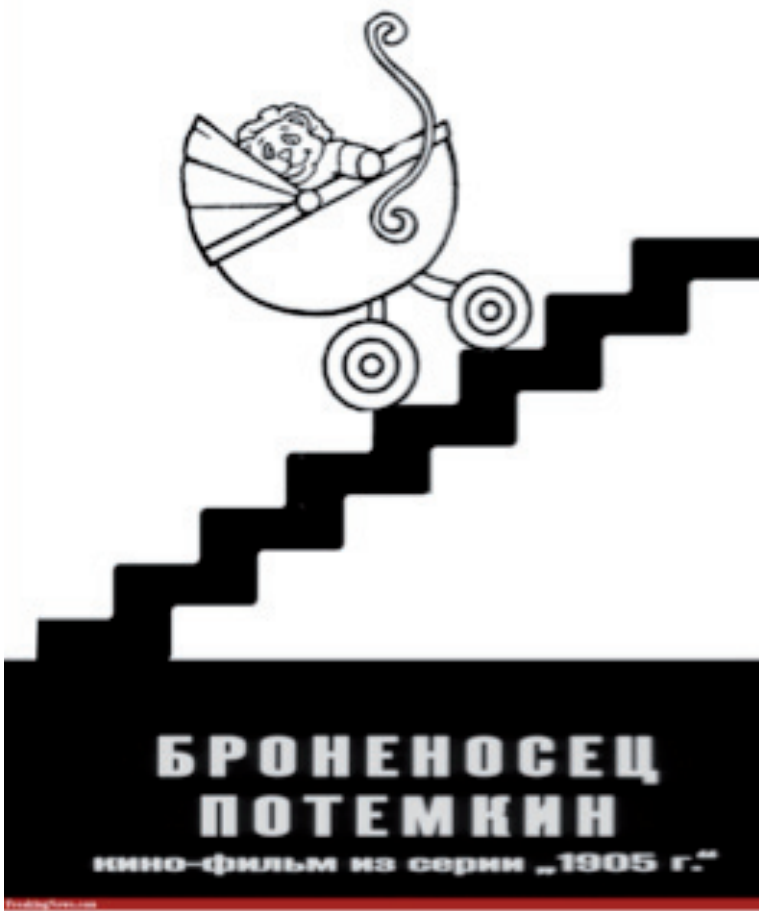

- Fig.6. Brian de Palma: The Untouchables (USA, 1987). Screenshot by Ulrich Blanché. 